\title{
Yield and yield components of papaya grown on Coto clay (Typic Eutrustox) and fertilized with chicken manure ${ }^{1}$
}

\author{
Miguel A. Muñoz ${ }^{2}$, Nydia Rafols ${ }^{3}$ and Julia M. O'Hallorans ${ }^{4}$
}

J. Agric. Univ. P.R. 88(3-4):123-134 (2004)

\begin{abstract}
A field experiment was established on Coto clay (Typic Eutrustox) to evaluate the use of chicken manure as fertilizer for papaya. Four manure rates $(0,5,10$ and $15 \mathrm{t} / \mathrm{ha})$ were evaluated in all possible combinations with four rates of inorganic fertilizer $(0,56,112$ and $224 \mathrm{~g} / \mathrm{plant} / \mathrm{month}$ of 15-1515). Fresh and dry weight of papaya leaves (petioles and blades) increased significantly with manure applications, but no effect of inorganic fertilizer treatments was observed. Phosphorus and potassium concentration in papaya blades was higher in plots receiving 15 tha of chicken manure. Fertilizer applications increased $K$ content in blades and decreased magnesium content. Both manure and fertilizer treatments increased fruit yield. The application of 10 and 15 t/ha of manure resulted in fruit yields of 42.19 and $54.76 \mathrm{t} / \mathrm{ha}$. These yields were significantly higher than the yields obtained with the 0 and $5 \mathrm{t} /$ ha treatments. The $0,56,112$ and $224 \mathrm{~g} / \mathrm{plant} / \mathrm{month}$ fertilizer treatments resulted in fruit yields of $28.11,42.60,37.22$ and $38.25 \mathrm{t} / \mathrm{ha}$, respectively. The yield of the 0 fertilizer treatment was significantly lower, but no significant difference was observed among the other fertilizer treatments. Chicken manure applications increased soil available phosphorus (Bray 1-P) from 16.57 to $28.64 \mathrm{mg} / \mathrm{kg}$, and soil exchangeable potassium from 0.12 to $0.19 \mathrm{cmol} / \mathrm{kg}$. Fertilizer applications had no significant effect on these two parameters. A significant correlation was observed between papaya yield and Bray 1-P. A Pearson correlation coefficient of 0.65 was obtained when both manure and inorganic fertilizer plots were considered. The correlation coefficient increased to $\mathbf{0 . 8 2}$ when only manure-treated plots were considered, but decreased to $\mathbf{0 . 2 5}$ when only fertilizer-treated plots were considered. Manure applications were more effective in increasing soil available phosphorus than fertilizer applications. Manure applications apparently prevent phosphorus fixation on Coto clay, increasing soil available phosphorus and thus favoring higher fruit yields.
\end{abstract}

Key words: organic fertilizer, Carica papaya, available phosphorus, chicken manure

${ }^{1}$ Manuscript submitted to Editorial Board 21 January 2004.

${ }^{2}$ Researcher, Agronomy and Soils Department, University of Puerto Rico-Mayagüez Campus, P.O. Box 9030, Mayagüez, PR 00681.

${ }^{3}$ Former Research Assistant, Agronomy and Soils Department.

${ }^{4}$ Assistant Researcher, Agronomy and Soils Department. 


\title{
RESUMEN
}

\author{
Rendimiento y componentes de rendimiento de papaya \\ fertilizada con gallinaza en un suelo Coto (Typic Eutrustox)
}

Se estableció un experimento en un suelo Coto (Typic Eutrustox) para evaluar el uso de gallinaza como fertilizante para papaya. Cuatro niveles de gallinaza $(0,5,10$ y 15 tha) y cuatro niveles de fertilizante inorgánico 15-15$15(0,56,112$ y $224 \mathrm{~g} /$ planta/mes) se evaluaron en todas las posibles combinaciones. Las aplicaciones de gallinaza aumentaron significativamente el peso fresco y seco de las hojas (peciolos y láminas), pero no se observó efecto alguno del fertilizante inorgánico. Las concentraciones de fósforo y potasio aumentaron significativamente en las láminas con la aplicación de 15 tha de gallinaza. Las aplicaciones de fertilizante aumentaron el contenido de potasio de las láminas y disminuyeron el contenido de magnesio. La producción de papaya aumentó significativamente con las aplicaciones de gallinaza y fertilizante. La aplicación de 10 y 15 t/ha de gallinaza resultó en una producción de frutas de 42.19 y 54.75 tha, respectivamente. Estas producciones fueron significativamente superiores a las obtenidas con las aplicaciones de 0 y 5 t/ha. Los tratamientos de $0,56,112$ y $224 \mathrm{~g} / \mathrm{planta} / \mathrm{mes}$ de fertilizante resultaron en una producción de frutas de 28.11, 42.60, 37.22 y $38.25 \mathrm{t} / \mathrm{ha}$, respectivamente. La producción obtenida con el tratamiento de 0 fertilizante fue significativamente inferior a las de los otros tratamientos, las cuales fueron similares entre sí. Las aplicaciones de gallinaza aumentaron el fósforo disponible (Bray 1-P) de 16.57 a $28.64 \mathrm{mg} / \mathrm{kg}$ y el potasio intercambiable de 0.12 a $0.19 \mathrm{cmol} / \mathrm{kg}$. Las aplicaciones de fertilizante no afectaron estos dos parámetros. Se observó una correlación significativa entre la producción de frutas y el Bray 1-P. El coeficiente de correlación de Pearson fue 0.65 cuando se consideraron todas las parcelas experimentales. Este coeficiente aumentó a $\mathbf{0 . 8 2}$ al considerarse solamente las parcelas tratadas con gallinaza, y disminuyó a 0.25 al considerarse solamente las parcelas tratadas con fertilizante. La gallinaza fue más efectiva que el fertilizante en aumentar el fósforo disponible del suelo. La gallinaza aparentemente previene la fijación de fósforo en el suelo Coto, aumentando su disponibilidad y propiciando una mayor producción de frutas.

Palabras clave: fertilizante orgánico, Carica papaya, fósforo disponible, gaIlinaza

\section{INTRODUCTION}

Poultry production is the second agricultural commodity in economic importance in Puerto Rico, contributing $\$ 84.6$ million to the agricultural gross income in 2000-01, with a production of 51.2 million kilograms (Department of Agriculture of Puerto Rico, 2002). This industry generates about 2,000 jobs in production, processing and marketing operations. Poultry producers are facing the problem of appropriate disposal of the manure in order to comply with environmental regulations. Inadequate management and disposal can cause serious contamination to surface and ground water resources, diminishing the water quality of aquifers, waterways, streams, rivers and lakes (Martínez et al., 1999; Moore et al., 2000).

The average yearly population of poultry chickens in Puerto Rico is approximately 8.2 million. A population of this size yields approxi- 
mately 72,000 metric tons of manure every year. In addition, Puerto Rico has a population of 1.4 million layers and 159,000 fighting cocks, which also contribute significantly to the manure production. Appropriate disposal of the manure will require a combination of alternatives such as composting, using it as fertilizer, animal feeding and energy production (Esteves, 1992; Muñoz, 1992; Randel, 1992; Soldevila, 1992).

The use of chicken manure as fertilizer provides a useful and practical approach for its disposal. The material is used to a small extent as fertilizer for plantains, bananas, pasture and fruit crops (Muñoz et al., 1990; Muñoz and Martínez, 1991; O’Hallorans et al., 1993). Composted manure has also been used as organic fertilizer and a growing media component for ornamental crops. However, reliable scientific data on the most adequate rates for specific crops, on frequency and mode of application, and on the effect manure applications have on soil properties are lacking.

The study herein reported was conducted to evaluate the potential of chicken manure as fertilizer for papaya cv. Sunrise. Papaya is a minor crop in Puerto Rico, concentrated mostly in the mountain region, where small multicropping farms are common. The production of papaya in 2000-01 was $1,623 \mathrm{t}$, with a farm value of $\$ 599,000$. However, there is great potential for increasing production, especially of the Solo type papaya, which has great acceptance as fresh fruit. Papaya is a high nutrient -demanding crop, which requires frequent applications of fertilizer (Pérez and Vargas, 1977). The characteristically slow nutrient release capacity of chicken manure makes it a practical and useful source of fertilizer for this crop.

\section{MATERIALS AND METHODS}

A field experiment was established at the Isabela Substation, located in the northwest part of Puerto Rico to evaluate the effect of chicken manure on papaya growth and yield. The Solo type, cultivar Sunrise was used as the test crop. The soil at the site is classified as Coto clay (very-fine, kaolinitic, isohyperthermic Typic Eutrustox). A composite soil sample of the first $20 \mathrm{~cm}$ was collected at the site for chemical analysis prior to treatment application. Soil $\mathrm{pH}$, measured in a 1:2 soil:water ratio, was 6.19; and available Bray 1-P was $9.67 \mathrm{mg} / \mathrm{kg}$. Exchangeable potassium, calcium and magnesium contents, extracted with $1 \mathrm{~N}$ ammonium acetate at $\mathrm{pH} 7$, were $0.07,7.65$ and $0.99 \mathrm{cmol} / \mathrm{kg}$, respectively. Soil organic matter content was $1.62 \%$.

Four manure rates $(0,5,10$ and $15 \mathrm{t} / \mathrm{ha})$ were evaluated in all possible combinations with four $15-15-15\left(\mathrm{~N}-\mathrm{P}_{2} \mathrm{O}_{5}-\mathrm{K}_{2} \mathrm{O}\right)$ fertilizer rates $(0$, 56,112 and $224 \mathrm{~g} /$ plant/month). The sixteen treatments were arranged 
in a Randomized Complete Block Design, with three replications. The manure was mixed with rice hulls, which is used as bedding material for the chickens. The manure was collected from poultry houses and immediately applied to the experimental plots, broadcast and incorporated into the soil to a depth of $15 \mathrm{~cm}$. Total chemical analysis of the chicken manure showed a nitrogen content of $4.75 \%$; phosphorus, $1.30 \%$; potassium, $1.32 \%$; calcium, $0.80 \%$; magnesium, $0.82 \%$.

Each experimental unit $\left(30 \mathrm{~m}^{2}\right)$ consisted of nine plants, for a total plant population of 3,000 plants per hectare. The papaya seedlings were transplanted at 60 days after seeding, when seedlings were about $30 \mathrm{~cm}$ tall. The planting distance was $1.83 \mathrm{~m}$ between rows and within the row. Eight days after planting, the inorganic fertilizer plots received an application of $56 \mathrm{~g}$ of $15-15-15\left(\mathrm{~N}_{-} \mathrm{P}_{2} \mathrm{O}_{5}-\mathrm{K}_{2} \mathrm{O}\right)$ fertilizer formula per plant. From there on, the inorganic fertilizer treatments were applied on a monthly basis up to eleven months, totaling ten applications. Drip irrigation was applied as needed.

Data on plant height, stem diameter, leaf fresh and dry weight (petioles and blades) were collected six months after planting. Plant height was measured from ground level to the terminal bud, and stem diameter was measured at $91 \mathrm{~cm}$ above ground level. A sample of four mature leaves (petiole plus blade) per plot was collected also at six months after planting for fresh and dry weight determination and nutrient content analysis. Dry weight was determined by drying the samples to constant weight in a forced-air oven at $70^{\circ} \mathrm{C}$. Nutrient content in tissue samples was determined by the wet ashing method (Westerman et al., 1990). Nitrogen and phosphorus were determined colorimetrically with a Technichon II Autoanalyzer. Potassium was determined by atomic emission, and calcium and magnesium by atomic absorption with a Perkin Elmer 2380 AAS.

Following recommended procedures, we collected soil samples $(0$ to $20 \mathrm{~cm}$ ) at six months after planting and analyzed them for $\mathrm{pH}$, available Bray 1-P and exchangeable cations (Page et al., 1982). The first picking of fruits was at eight months after planting. Subsequent harvests were on a weekly basis. A total of 20 harvests were performed. Data were analyzed by using analysis of variance (ANOVA) and means comparisons by the Tukey test. Pearson correlation coefficients were applied to test the relationship between available phosphorus and yield.

\section{RESULTS AND DISCUSSION}

Fresh and dry weight of papaya leaves (blades and petioles) increased significantly with chicken manure treatments, but no significant differences were observed among fertilizer treatments (Table 
TABLE 1. Effect of manure and fertilizer treatments on fresh and dry weight (g/sample) of papaya petioles and blades.

\begin{tabular}{|c|c|c|c|c|}
\hline \multirow[t]{2}{*}{ Manure (t/ha) } & \multicolumn{2}{|c|}{ Petioles } & \multicolumn{2}{|c|}{ Blades } \\
\hline & Dry & Fresh & Dry & Fresh \\
\hline 0 & $172.8 c^{1}$ & $13.4 \mathrm{~b}$ & $152.1 \mathrm{c}$ & $28.5 \mathrm{c}$ \\
\hline 5 & $196.9 \mathrm{bc}$ & $14.5 \mathrm{~b}$ & $164.9 \mathrm{bc}$ & $30.1 \mathrm{bc}$ \\
\hline 10 & $275.3 \mathrm{ab}$ & $24.0 \mathrm{ab}$ & $215.8 \mathrm{ab}$ & $40.1 \mathrm{ab}$ \\
\hline 15 & $346.4 \mathrm{a}$ & 32.8 a & $266.5 \mathrm{a}$ & $47.7 \mathrm{a}$ \\
\hline \multicolumn{5}{|l|}{$\begin{array}{l}\text { Fertilizer } \\
\text { (g/plant/month) }\end{array}$} \\
\hline 0 & $216.3 a$ & $20.5 \mathrm{a}$ & $177.5 \mathrm{a}$ & $34.0 \mathrm{a}$ \\
\hline 56 & $266.1 \mathrm{a}$ & $21.6 \mathrm{a}$ & $266.1 \mathrm{a}$ & $39.0 \mathrm{a}$ \\
\hline 112 & $248.8 \mathrm{a}$ & $21.8 \mathrm{a}$ & $248.8 \mathrm{a}$ & $36.2 \mathrm{a}$ \\
\hline 224 & $260.3 \mathrm{a}$ & $20.9 a$ & $260.3 \mathrm{a}$ & $37.2 \mathrm{a}$ \\
\hline
\end{tabular}

${ }^{1}$ Means in the same column followed by the same letter or sequence of letters are not significantly different at the $5 \%$ level by the Tukey test.

1). Fresh and dry weight of blades and petioles of papaya plants receiving $15 \mathrm{t} /$ ha of chicken manure was significantly higher than that of the 0 and $5 \mathrm{t} /$ ha treatments, but similar to that of the $10 \mathrm{t} / \mathrm{ha}$ treatment. Petioles had higher fresh weights and lower dry weights than blades. Water content in petioles represented about $90 \%$ of total fresh weight, whereas in leaves it was about $80 \%$. After obtaining similar results, Pérez and Vargas (1977) suggested that petioles serve as a water storage tissue. We did not observe significant differences in plant height or stem diameter among fertilizer or manure treatments (data not shown).

Percentage of nutrient content in blades and petioles is shown in Tables 2 and 3. A significant increase in phosphorus and potassium content in papaya blades was observed with the application of $15 \mathrm{t} / \mathrm{ha}$ of manure when compared to that of the 0 manure treatment. No significant differences were observed in nitrogen, calcium and magnesium content of blades. For the fertilizer treatments, a significantly lower potassium content was observed in the 0 treatment. The 56, 112 and 224 $\mathrm{g} / \mathrm{plant} /$ month treatments showed similar nutrient contents. The magnesium content of blades decreased with the application of fertilizer, an effect not observed with manure applications. Chicken manure contains $0.82 \% \mathrm{Mg}$ and apparently provides a better balance between magnesium and potassium availability in the soil. These two cations compete for entrance through plant roots, and reports on magnesium deficiencies induced by high levels of potassium are common (Claassen and Wilcox, 1974; Claassen and Barber, 1977; Hannaway et al., 1980; Salmon, 1964). A similar pattern was observed in nutrient content of 
TABLE 2. Effect of manure and fertilizer treatments on nutrient content (\%) in papaya blades.

\begin{tabular}{lccccc}
\hline & \multicolumn{5}{c}{ Nutrient Content (\%) } \\
\cline { 2 - 6 } Manure (t/ha) & $\mathrm{N}$ & $\mathrm{P}$ & $\mathrm{K}$ & $\mathrm{Ca}$ & $\mathrm{Mg}$ \\
\hline 0 & $5.01 \mathrm{a}$ & $0.45 \mathrm{~b}^{1}$ & $1.82 \mathrm{~b}$ & $2.04 \mathrm{a}$ & $0.91 \mathrm{a}$ \\
5 & $5.14 \mathrm{a}$ & $0.47 \mathrm{ab}$ & $2.02 \mathrm{ab}$ & $1.99 \mathrm{a}$ & $0.90 \mathrm{a}$ \\
10 & $5.38 \mathrm{a}$ & $0.49 \mathrm{ab}$ & $2.00 \mathrm{ab}$ & $2.10 \mathrm{a}$ & $0.93 \mathrm{a}$ \\
15 & $5.29 \mathrm{a}$ & $0.50 \mathrm{a}$ & $2.16 \mathrm{a}$ & $2.12 \mathrm{a}$ & $0.90 \mathrm{a}$ \\
Fertilizer & & & & & \\
g/plant/month) & & & & & \\
0 & $5.21 \mathrm{a}$ & $0.49 \mathrm{a}$ & $1.67 \mathrm{~b}$ & $2.25 \mathrm{a}$ & $0.99 \mathrm{a}$ \\
56 & $5.25 \mathrm{a}$ & $0.47 \mathrm{a}$ & $1.99 \mathrm{a}$ & $2.02 \mathrm{a}$ & $0.90 \mathrm{~b}$ \\
112 & $5.17 \mathrm{a}$ & $0.47 \mathrm{a}$ & $2.16 \mathrm{a}$ & $2.00 \mathrm{a}$ & $0.90 \mathrm{~b}$ \\
224 & $5.19 \mathrm{a}$ & $0.48 \mathrm{a}$ & $2.18 \mathrm{a}$ & $1.98 \mathrm{a}$ & $0.86 \mathrm{~b}$ \\
\hline
\end{tabular}

${ }^{1}$ Means followed by the same letter are not significantly different at the $5 \%$ level by the Tukey test.

petioles. Fertilizer applications significantly increased nitrogen and potassium content of petioles, but decreased calcium and magnesium content (Table 3). In most cases, nitrogen, phosphorus and potassium content in petioles and blades of papaya were higher than the critical values reported in the literature for optimum yields (Awada, 1969; Awada and Long, 1969; Awada and Long, 1970). Awada (1969) reported critical nitrogen levels of $1.25 \%$ in petioles and of $4.52 \%$ in papaya blades. In our study, nitrogen percentage in petioles ranged from 1.36

TABLE 3. Effect of manure and fertilizer treatments on nutrient content (\%) in papaya petioles.

\begin{tabular}{lccccc}
\hline & \multicolumn{5}{c}{ Nutrient Content (\%) } \\
\cline { 2 - 6 } Manure (t/ha) & $\mathrm{N}$ & $\mathrm{P}$ & $\mathrm{K}$ & $\mathrm{Ca}$ & $\mathrm{Mg}$ \\
\hline 0 & $1.36 \mathrm{a}$ & $0.28 \mathrm{a}$ & $3.34 \mathrm{a}$ & $1.78 \mathrm{a}$ & $0.54 \mathrm{a}$ \\
5 & $1.44 \mathrm{a}$ & $0.31 \mathrm{a}$ & $3.85 \mathrm{a}$ & $1.62 \mathrm{a}$ & $0.53 \mathrm{a}$ \\
10 & $1.60 \mathrm{a}$ & $0.32 \mathrm{a}$ & $3.63 \mathrm{a}$ & $1.62 \mathrm{a}$ & $0.53 \mathrm{a}$ \\
15 & $1.57 \mathrm{a}$ & $0.32 \mathrm{a}$ & $3.85 \mathrm{a}$ & $1.53 \mathrm{a}$ & $0.49 \mathrm{a}$ \\
Fertilizer & & & & & \\
(g/plant/month) & & & & & \\
0 & $1.26 \mathrm{~b}$ & $0.31 \mathrm{a}$ & $3.03 \mathrm{~b}$ & $1.93 \mathrm{a}$ & $0.64 \mathrm{a}$ \\
56 & $1.52 \mathrm{a}$ & $0.30 \mathrm{a}$ & $3.54 \mathrm{ab}$ & $1.59 \mathrm{~b}$ & $0.50 \mathrm{~b}$ \\
112 & $1.57 \mathrm{a}$ & $0.30 \mathrm{a}$ & $4.15 \mathrm{a}$ & $1.50 \mathrm{~b}$ & $0.48 \mathrm{~b}$ \\
224 & $1.62 \mathrm{a}$ & $0.30 \mathrm{a}$ & $3.97 \mathrm{a}$ & $1.52 \mathrm{~b}$ & $0.47 \mathrm{~b}$ \\
\hline
\end{tabular}

${ }^{1}$ Means followed by the same letter are not significantly different at the $5 \%$ level by the Tukey test. 
to $1.60 \%$ for the manure treatments and from 1.26 to $1.62 \%$ for the fertilizer treatments (Table 3 ). Nitrogen content in the blades ranged from 5.01 to $5.38 \%$ for the manure treatments, and from 5.17 to $5.25 \%$ for the fertilizer treatments (Table 2). A critical level of $0.25 \% \mathrm{P}$ in recently mature petioles was reported by Awada and Long (1969). In our study phosphorus levels in petioles ranged from 0.28 to 0.32 and from 0.45 to $0.50 \%$ in blades. The critical level of potassium reported by Awada and Long (1970) in mature petioles was $3.61 \%$. In our study, potassium content in petioles ranged from 3.34 to $3.85 \%$ for the manure treatments, and from 3.03 to $4.15 \%$ for the fertilizer treatments. The only treatments showing potassium content below $3.61 \%$ were the 0 manure treatment, the 0 fertilizer treatment and the $56 \mathrm{~g} / \mathrm{plant} / \mathrm{month}$ fertilizer treatment (Table 3).

Fruit yield increased significantly with manure and fertilizer applications (Table 4). The application of 10 and $15 \mathrm{t} / \mathrm{ha}$ of manure resulted in fruit yields of 42.19 and $54.76 \mathrm{t} / \mathrm{ha}$. These treatments outyielded the 0 and 5 t/ha treatments. Fruit yield in fertilized plots was significantly higher than the yield obtained for the 0 fertilizer treatment. These results indicate that rates of 112 and $224 \mathrm{~g} / \mathrm{plant} / \mathrm{month}$ of a fertilizer formula 15-15-15 are not necessary to attain optimum yields in this soil. A rate of $227 \mathrm{~g} / \mathrm{plant} / \mathrm{month}$ was recommended by Pérez and Vargas (1977) for optimum yields with the cultivars PR 6-65 and PR 7-65 grown also on Coto soil, and using a similar plant population. This rate has been recommended and used for the Solo type papaya varieties. Excessive use of fertilizer represents a waste of money for the farmer and raises serious concerns on the negative environmental impact that may result from such practice (Martínez et al., 1999; Moore et al., 2000).

The beneficial effect of manure on papaya performance and yield is attributed to its nutrient content and to its beneficial effect on soil chemical properties. Chicken manure applications significantly increased soil available phosphorus and exchangeable $\mathrm{K}^{+}$, but did not affect soil $\mathrm{pH}$, or exchangeable $\mathrm{Ca}^{2+}$ and $\mathrm{Mg}^{2+}$ (Table 5). No signifi-

TABLE 4. Effect of manure and fertilizer treatments on fruit yield.

\begin{tabular}{lccc}
\hline $\begin{array}{c}\text { Manure } \\
(\mathrm{t} / \mathrm{ha})\end{array}$ & $\begin{array}{c}\text { Yield } \\
(\mathrm{t} / \mathrm{ha})\end{array}$ & $\begin{array}{c}\text { Fertilizer } \\
(\mathrm{g} / \text { plant/month })\end{array}$ & $\begin{array}{c}\text { Yield } \\
(\mathrm{t} / \mathrm{ha})\end{array}$ \\
\hline 0 & $23.35 \mathrm{c}^{1}$ & 0 & $28.11 \mathrm{~b}$ \\
5 & $25.88 \mathrm{bc}$ & 56 & $42.60 \mathrm{a}$ \\
10 & $42.19 \mathrm{ab}$ & 112 & $37.22 \mathrm{a}$ \\
15 & $54.76 \mathrm{a}$ & 224 & $38.25 \mathrm{a}$ \\
\hline
\end{tabular}

${ }^{1}$ Means followed by the same letters are not significantly different at the $5 \%$ level by the Tukey test. 
TABLE 5. Effect of manure and fertilizer treatments on selected soil chemical properties.

\begin{tabular}{lccccc}
\hline Manure (t/ha) & $\mathrm{pH}$ & $\begin{array}{c}\text { Bray 1-P } \\
(\mathrm{mg} / \mathrm{kg})\end{array}$ & $\begin{array}{c}\text { Exchangeable } \\
\mathrm{K}^{+}\end{array}$ & $\begin{array}{c}\text { Cations }\left(\mathrm{cmol}_{\mathrm{c}} / \mathrm{kg}\right) \\
\mathrm{Ca}^{2+}\end{array}$ & $\mathrm{Mg}^{2+}$ \\
\hline 0 & $5.55 \mathrm{a}$ & $16.57 \mathrm{c}^{1}$ & $0.12 \mathrm{c}$ & $4.08 \mathrm{a}$ & $0.69 \mathrm{a}$ \\
5 & $5.36 \mathrm{a}$ & $20.95 \mathrm{bc}$ & $0.14 \mathrm{bc}$ & $3.52 \mathrm{a}$ & $0.70 \mathrm{a}$ \\
10 & $5.42 \mathrm{a}$ & $24.96 \mathrm{ab}$ & $0.17 \mathrm{ab}$ & $3.63 \mathrm{a}$ & $0.67 \mathrm{a}$ \\
15 & $5.57 \mathrm{a}$ & $28.64 \mathrm{a}$ & $0.19 \mathrm{a}$ & $3.99 \mathrm{a}$ & $0.79 \mathrm{a}$ \\
Fertilizer & & & & & \\
(g/plant/month) & & & & & \\
0 & $5.52 \mathrm{a}$ & $22.15 \mathrm{a}$ & $0.16 \mathrm{a}$ & $3.90 \mathrm{a}$ & $0.66 \mathrm{a}$ \\
56 & $5.48 \mathrm{a}$ & $23.55 \mathrm{a}$ & $0.14 \mathrm{a}$ & $3.81 \mathrm{a}$ & $0.70 \mathrm{a}$ \\
112 & $5.44 \mathrm{a}$ & $22.83 \mathrm{a}$ & $0.17 \mathrm{a}$ & $3.68 \mathrm{a}$ & $0.74 \mathrm{a}$ \\
224 & $5.47 \mathrm{a}$ & $22.58 \mathrm{a}$ & $0.17 \mathrm{a}$ & $3.83 \mathrm{a}$ & $0.76 \mathrm{a}$ \\
\hline
\end{tabular}

${ }^{1}$ Means followed by the same letters are not significantly different at the $5 \%$ level by the Tukey test.

cant differences in these soil parameters were observed among fertilizer treatments (Table 5) although the amount of potassium applied was higher and the amount of phosphorus applied was similar. The potassium and phosphorus content of the manure were 1.32 and $1.30 \%$, respectively. A previous study (Muñoz et al., 1990) indicated that the potassium and phosphorus content of chicken manure were extracted almost entirely by $1 \mathrm{~N}$ ammonium acetate and Bray extracting solutions. This finding is an indication of the high availability of these two nutrients present in the manure. Soil available phosphorus for the 0 manure treatment was $16.57 \mathrm{mg} / \mathrm{kg}$ and increased to $28.64 \mathrm{mg} / \mathrm{kg}$ with the application of $15 \mathrm{t} / \mathrm{ha}$ of manure. The highest concentration of Bray 1-P among fertilizer treatments was $22.83 \mathrm{mg} / \mathrm{kg}$, but no significant differences were observed among them. A concentration of $20 \mathrm{mg} / \mathrm{kg}$ of Bray 1-P has been suggested as a critical level for optimum yields in tropical regions (Muñiz, 1992). A significant correlation was observed between soil available phosphorus and fruit yield (Figure 1). A significant Pearson correlation coefficient of 0.65 was obtained when all experimental plots were considered. However, a higher Pearson correlation coefficient $(0.86)$ was obtained when only average values for manure-treated plots were considered (Figure 2). The Pearson correlation coefficient for available phosphorus and yield when only average values for fertilizer treated plots were considered was 0.25 , and it was not significant (Figure 3). This finding confirms the beneficial effects of manure applications in improving phosphorus availability in Coto clay, and in improving yields. 


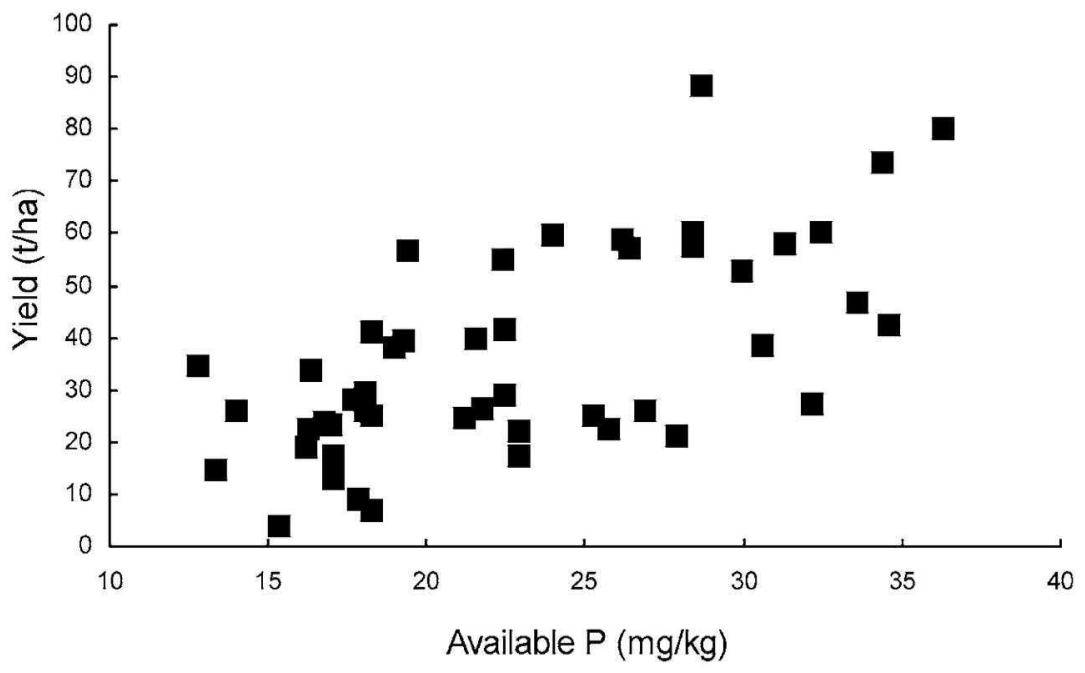

FIGURE 1. Relationship between soil available phosphorus (Bray 1) and papaya yield. (Pearson corr. coeff. $=0.65$ )

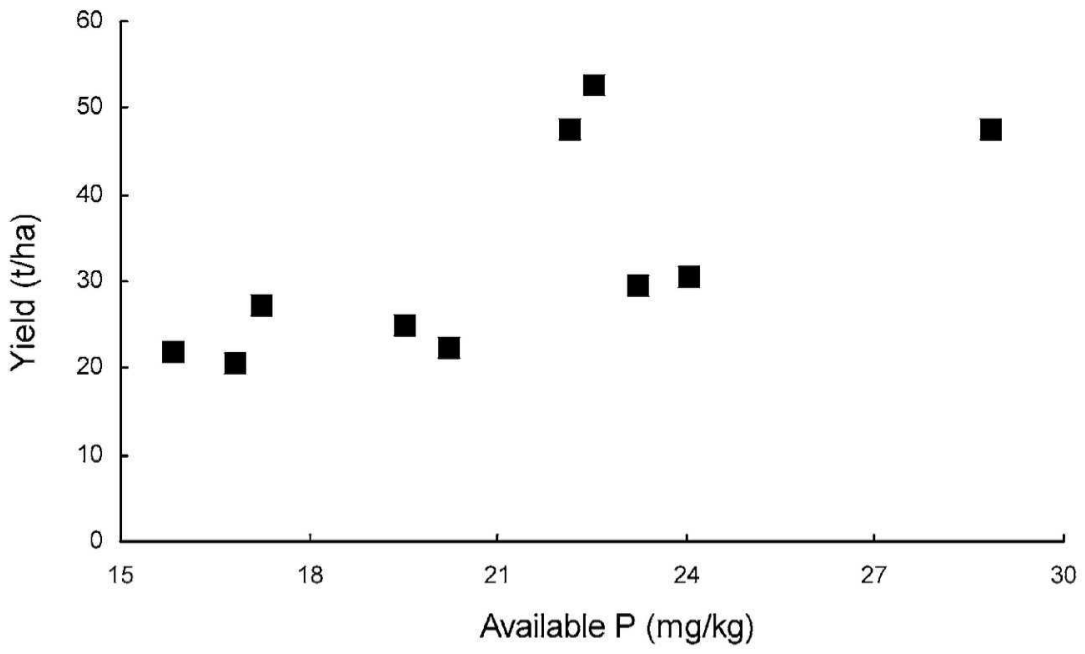

FIGURE 2. Relationship between soil available phosphorus (Bray 1) and papaya yield on plots fertilized with manure. (Pearson corr. coeff. $=0.86$ ) 


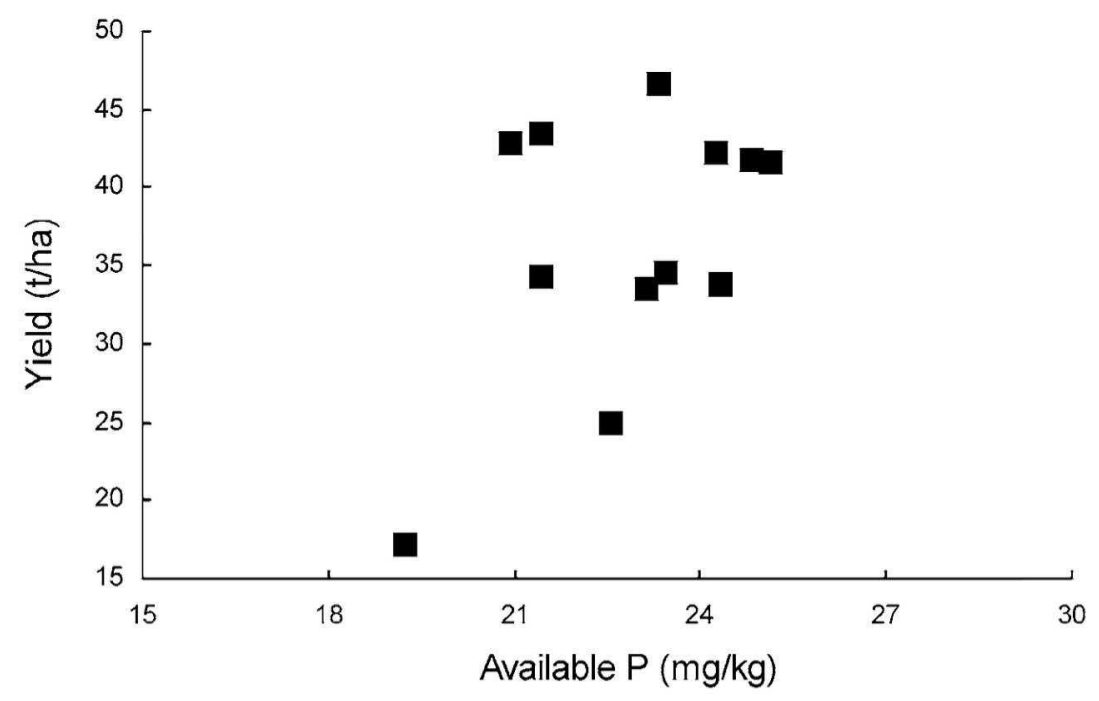

FIGURE 3. Relationship between soil available phosphorus (Bray 1) and papaya yield on plots fertilized with inorganic fertilizer. (Pearson corr. coeff. $=0.25$ )

The phosphorus applied as inorganic fertilizer apparently is readily fixed on Coto clay, thus reducing its availability to the crop. Organic anions in the manure may have enhanced phosphorus availability by competing with phosphate for adsorption sites on Coto clay and/or by neutralization of exchangeable $\mathrm{Al}^{3+}$ (Hue, 1991, 1992; O'Hallorans et al., 1997). Hue (1992) suggested that organic acids compete with phosphorus for adsorption sites on highly weathered soils, increasing the availability of phosphorus. They stated that the efficiency of phosphorus fertilizers could be increased markedly if these were applied along with organic acids, or with materials such as green manure or animal wastes. These effects should provide a better soil environment for plant growth and yield. O'Hallorans et al. (1997) suggested that organic anions from the manure may also be involved in the reduction or neutralization of exchangeable aluminum and in the increase of soil available phosphorus. The role of anions of organic acids, such as citric, oxalic, malic and aminoacids, in complexation and detoxification of soil exchangeable aluminum has been demonstrated in other studies (Ahmad and Tan, 1986; Jones and Darrah, 1994; Wong et al., 2000; Kollmeier et al., 2001). These acids have been identified as products of the decomposition of organic matter, decomposition of manure and root exudates. 
Chicken manure is an excellent fertilizer for papaya, especially in highly weathered soils where phosphorus availability is low. The application of $10 \mathrm{t} / \mathrm{ha}$ of manure satisfies the nutrient demand of the crop and results in optimum yields. The recommendation of $227 \mathrm{~g} / \mathrm{plant} /$ month of 15-15-15 inorganic fertilizer should be re-evaluated, since our results indicate that similar yields can be reached with the application of $56 \mathrm{~g} / \mathrm{plant} / \mathrm{month}$. The manure will be more effective if it is applied fresh and incorporated into the soil. Soil incorporation will prevent nitrogen losses by volatilization, reduce unpleasant odors and will reduce manure loss by erosion.

\section{LITERATURE CITED}

Ahmad, F. and K. H. Tan, 1986. Effect of lime and organic matter on soybean seedlings grown in aluminum-toxic soil. Soil Sci. Soc. Am. J. 50:656-661.

Awada, M., 1969. The selection of the nitrogen index in papaya tissue analysis. J. Amer. Soc. Hort. Sci. 94(6):687-690.

Awada, M. and C. Long, 1969. The selection of the phosphorus index in papaya tissue analysis. J. Amer. Soc. Hort. Sci, 94:501-504.

Awada, M. and C. Long, 1970. The selection of the potassium index in papaya tissue analysis. J. Amer. Soc. Hort. Sci. 96(1):74-77.

Claassen, M. E. and G. E. Wilcox, 1974. Comparative reduction of calcium and magnesium composition of corn tissue by $\mathrm{NH}_{4}-\mathrm{N}$ and $\mathrm{K}$ fertilization. Agron. J. 66:521-522.

Claassen, N. and S. A. Barber, 1977. Potassium influx characteristics of corn roots and interaction with N, P, Ca, and Mg influx. Agron. J. 69:860-864.

Department of Agriculture of Puerto Rico, 2002. Ingreso Bruto Agrícola 2001-2002. Oficina de Estadísticas Agrícolas. San Juan, Puerto Rico.

Esteves, G., 1992. Nueva alternativa para disponer de la gallinaza y los desperdicios en el proceso industrial de pollos parrilleros. Memorias Foro Conversión y Uso de la Gallinaza en Puerto Rico. Agric. Exp. Stn. 49 p.

Hannaway, D. B., L. P. Bush and J. E. Leggett, 1980. Plant nutrition: magnesium and hypomagnesemia in animals. Bull. 716 Agric. Exp. Stn. Univ. of Kentucky, Lexington.

Hue, N. V., 1991. Effect of organic acids/anions on P sorption and phytoavailability in soils with different mineralogies. Soil Sci. 152:463-471.

Hue, N. V., 1992. Correcting soil acidity of a highly weathered Ultisol with chicken manure and sewage sludge. Commun. Soil Sci. Plant Anal. 23(3-4):241-264.

Jones, D. L. and P. R. Darrah, 1994. Role of root derived organic acids in the mobilization of nutrients from the rhizosphere. Plant and Soil 166:247-257.

Kollmeier, M., P. Dietrich, C. S. Bauer, W. J. Horst and R. Hedrich, 2001. Aluminum activates a citrate-permeable anion channel in the aluminum-sensitive zone of the maize root apex. A comparison between an aluminum-sensitive and an aluminumresistant cultivar. Plant Physiol. 126:397-410.

Martínez, G. A., L. Olivieri, J. A. Castro, O. Muñiz-Torres and J. L. Guzmán, 1999. Phosphorus status of soils from the poultry zone in Puerto Rico. J. Agric. Univ. P. R. 83(1-2):1-17.

Moore, P. A., T. C. Daniel and D. R. Edwards, 2000. Reducing phosphorus runoff and inhibiting ammonia loss from poultry manure with aluminum sulfate. d. Environ. Qual. 29:37-49. 
Muñiz, O., 1992. El uso de fertilizantes en Puerto Rico: Enfoques prácticos. Agric. Ext. Serv., UPR Mayagüez. $19 \mathrm{p}$.

Muñoz, M. A., 1992. Uso de la gallinaza como fertilizante. Memorias Foro Conversión y uso de gallinaza en Puerto Rico. Agric. Exp. Stn. U.P.R. 49 p.

Muñoz, M. A., O. Colberg and J. A. Dumas, 1990. Chicken manure as an organic fertilizer. J.Agric. Univ. P. R. 74(2):139-144.

Muñoz, M. A. and G. Martínez, 1991. Chicken manure: An organic fertilizer for plantains (Musa acuminata $\times$ M. balbisiana AAB). Proc. Caribbean Food Crops Society 27:225-233.

O'Hallorans, J. M., M. A. Muñoz and O. Colberg, 1993. Effect of chicken manure on chemical properties of a Mollisol and tomato production. J. Agric. Univ. P. R. 77 (3\&4):181-191.

O'Hallorans, J. M., M. A. Muñoz and P. E. Márquez, 1997. Chicken manure as an amendment to correct soil acidity and fertility. J. Agric. Univ. P.R. 81(1-2):1-8.

Page, A. L., R. H. Miller and D. R. Keeney, 1982. Methods of Soil Analysis Part 2-Chemical and Microbiological Properties. Amer. Soc. Agron. Madison Wis, USA. 1159 p.

Pérez, A. and D. Vargas, 1977. Effect of fertilizer level and planting distance on soil pH, growth, disease incidence, yield, and net profit of two papaya varieties. J. Agric. Univ. P. R. 61(1):68-76.

Randel, P., 1992. Proyecto sobre la utilización de gallinaza aperdigonada. Memorias Foro Conversión y Uso de Gallinaza en Puerto Rico. Agric. Exp. Stn. U.P.R. 49 p.

Salmon, R. C., 1964. Cation-activity ratios in equilibrium soil solutions and availability of magnesium. Soil Sci. 98:213-221.

Soldevila, M., 1992. Camada curada como ingrediente alimenticio para bovinos, caprinos y ovinos en desarrollo. Memorias Foro Conversión y Uso de Gallinaza en Puerto Rico. Agric. Exp. Stn. U.P.R. 49 p.

Westerman, R. L., 1990. Soil Testing and Plant Analysis. Soil Sei. Soc. Am., Inc. Madison Wis., USA. 784 p.

Wong, M. T. F., P. Gibbs, S. Nortcliff and R. S. Swift, 2000. Measurement of the acid neutralizing capacity of agroforestry tree prunings added to tropical soils. J. Agric. Sci. 134:269-276. 